\title{
Retraction Note to: Late Quaternary stable isotope record and meltwater discharge anomaly events to the south of the Antarctic Polar Front, Drake Passage
}

\author{
Sung Ho Bae ${ }^{1} \cdot$ Ho II Yoon ${ }^{1} \cdot$ Byong-Kwon Park ${ }^{1} \cdot$ Yeadong Kim ${ }^{1}$ \\ Published online: 9 June 2020 \\ (C) Springer-Verlag GmbH Germany, part of Springer Nature 2020
}

Retraction Note to: Geo-Mar Lett (2003) 23: 110-116

https://doi.org/10.1007/s00367-003-0129-y

This article [1] has been retracted at the request of the Editorsin-Chief because it has been previously published by Bae, S.H., Yoon, H.I., Park, B. et al [2]. This article is therefore redundant. Yeadong Kim agrees to this retraction; Sung Ho Bae, Hi Il Yoon and Byong-Kwon Park have not responded to any correspondence from the editor/publisher about this retraction.

1. Bae, S.H., Yoon, H.I., Park, B. et al. Late Quaternary stable isotope record and meltwater discharge anomaly events to the south of the Antarctic Polar Front, Drake Passage. Geo-Mar Lett 23, 110-116 (2003) doi:10.1007/s00367-003-0129-y

2. Bae, S.H., Yoon, H.I., Park, B. et al. Meltwater discharge anomalies in marine isotope stage 3 from a sediment core in the south of Antarctic Polar Front, Drake Passage. Geosci J 7, 73-79 (2003) doi:10.1007/BF02910267

Publisher's note Springer Nature remains neutral with regard to jurisdictional claims in published maps and institutional affiliations.

The online version of the original article can be found at https://doi.org/ 10.1007/s00367-003-0129-y

Sung Ho Bae

shbae@kordi.re.kr

\footnotetext{
Polar Sciences Laboratory, Korea Ocean Research and Development Institute, P.O. Box 29, Ansan, Seoul 425-600, Korea
} 